\title{
Contributing Factors to Online Banking Adoption Among Customers in Kampala, Uganda
}

\author{
Festo Nyende Tusubira* Sharon Hilda Amaal \\ College of Business and Management Sciences, Makerere University, P.O. Box 7062, Kampala
}

\begin{abstract}
The advancement of technology has greatly impacted the nature of businesses pushing most from the traditional brick and wall to a virtual market. The Covid-19 strains in the past year have also immensely cut of human physical contact and spanned the conventional monetary exchange to a cashless platform. However, surveys still register that several Ugandans access bank services at the banking hall instead of using the internet that has been termed as more convenient, easy to use and widely accessible. This study therefore aimed at providing a deeper understanding of factors that contribute to the adoption of online banking in Kampala-Uganda. More specifically, the study explores perceived risk, perceived ease of use, perceived usefulness mediated by customer satisfaction as the contributing factors to online banking. into The study adopted the Technology Adoption Model (TAM) to develop the conceptual framework used. A cross sectional research design was employed to achieve the study aims and objectives together with a quantitative approach that used a survey questionnaire to collect data from 300 bank customers from Standard chartered, Centenary and Stanbic banks. The results revealed that perceived ease of use and perceived usefulness positively affected adoption of mobile banking and therefore should guide online adoption applications. However, the increase in perceived risks was found to not necessarily lead to a decline in the levels of adoption. This study therefore adds to the scant literature in the area of online banking especially in emerging countries like Uganda.
\end{abstract}

Keywords: Online banking, Adoption, Perceived risks, Perceived ease of use, Perceived usefulness, Customer satisfaction, TAM, Standard Chartered Bank, Stanbic Bank, Centenary Bank, Uganda.

DOI: $10.7176 /$ RJFA/12-10-07

Publication date:May $31^{\text {st }} 2021$

\section{Introduction}

According to the World Payments Report (2019), commercial banks registered stunt growths of $3.8 \%$ that fell to $2.7 \%$ between 2014 and 2016 . This decline potentially affected profitability and might have conveyed cognizance of risks related to the banking sector. In the same period, globalisation unlocked several benefits with regard to the use of technology that could well offer instant, real-time services to the banks' clientele. By 2013, card transactions were the main mode of transaction through alternative payment systems which was expected to rise at a rate of $59 \%$ by 2017 (World pay, 2014).

The continuous and yet rapid improvements in information, communication and technology sectors have challenged the world economy to go digital and interchange in a single space - the digital market. Businesses have opted for electronic strategies and processes to reduce operational costs, improve sales, and offer improved services to consumers who on the other hand moved on to a hands on customer service experience. The delivery of products and services most especially during the COVID-19 pandemic has majorly migrated to an online platform with consumers adapting to purchasing and paying for products through a cashless stream. This comes in response to maintain minimal contact with others, keep social distancing and limit the rate at which an item may be touched by several people to reduce and avoid contamination and contraction of the virus.

Having been introduced as early as the 1980s (Kalakota \& Whinston, 1997), online banking through an application software program provides remote banking services via a web portal (WWW) using internet connected to smartphones, desktop computers, tablets and Laptop computers. This can be used to access services such as payment of bills, online money transfers, make inquiries and carry out foreign exchange transfers (Lin, Wang \& Hung, 2020). Zwass (2003) concretely defines it as an electronic banking system that deploys banking products and services directly to customers over electronic and communication networks.

It may also be known as internet banking, e-banking, virtual banking and cyber banking. However, it is different from E-banking as it simply forms a part of the former, a higher level system that incorporates agent banking, Automated Teller Machines (ATM), Electronic Fund Transfers (EFT), Wireless Application Protocol (WAP), SWIFT and telephone banking

To be certain that the system has been adopted, customers who adapt to online banking should not only repeat usage but also extend word of mouth about it to their colleagues who will certainly be convinced and hence reduce the number of people queuing up in the banking halls. Notably, the US and Europe economies are characterised by the strong existence of technology. This has supported the adoption to new payment technologies. Developing markets in the Americas and Asia have an increasingly middle class population that is tech-savvy and more open to new ideas that result in innovation, technology and easily integrated transaction methods (Global payments, 
2020).

The banking industry of the 21 st century is facing a complex and ever changing environment due to the constant innovation and developments in the technological marketplace. (Ogare, 2013; Tseng \& Wei, 2020). In Qatar for instance, the stable economy, Islamic values and principles (Anouze \& Alamro, 2019) together with the considerable investments potential has catalysed the need and value of E-banking (Alkhowaiter, 2020). Therefore, web-based banking continues to evolve and stand as a competitive advantage used to attract and retain customers (Sadowski, 2017) in the financial sectors of developed economies. What is left now, is to ensure service quality in the process such as efficiency, reliability, security and privacy (Khatoon, Zhengliang, \& Hussain, 2020). This has a positive influence on customers purchasing intentions which is important in the survival of the business (Manju, 2020). One thing for certain in the MENA region is the level of involvement by the central banks and other regulatory bodies as they use traditional conservatism to protect family owned businesses from cyber-crime and encourage banking the unbanked. This has led to a broader level of financial inclusion (Global payments, 2020).

Anyona (2018) conducted a research in the CBD of Nairobi Kenya and concluded that most of the respondents strongly agreed that they used mobile banking systems to check on their account details and mini statements and make payments towards government and public utilities. However, when it came to the actual transfer of funds from one account to another or making loan and credit card payments, majority of the respondents disagreed. A similar study conducted in Sudan (Nancy, Siddig, \& Abdel, 2014) showed that bank customers are more likely to adopt $\mathrm{m}$-banking services if they find them easy to use with minimal efforts and yet the bank can provide protection for their confidential information.

Introduced to the Ugandan market as early as 1997, internet banking which forms part of the financial inclusion has been researched to result into poverty alleviation, increased commercial bank sales which all result into economic growth (Alliance for Financial Inclusion, 2019). After the automation of banking services in 1993, (Senoga, 2018), Standard chartered bank launched the first ATM in 1997 and other banks followed suit. Cerudeb (now Centenary Bank) followed in the subsequent year and participated in the Bankom interconnection electronic system that was introduced in 2004 to encourage and support the use of IT facilities within Ugandan banks. The Ugandan banking sector witnessed major turmoil between the late 1990s and early 2000s when several banks exited the market such as Greenland, Teefe, Gold Trust and Uganda Cooperative Banks. The remaining banks seized the market though growing and adapting to e-banking at rates of $30 \%$ and $49 \%$ below projected levels.

In regards to Vision 2020, Bank of Uganda (BOU) became a member of the Alliance for Financial Inclusion (AFI) in 2011 ultimately raising financial service usage from 52\% in 2013 to 58\% in 2018. Emphasis has since been placed on digital financial services, an ecosystem that comprises mobile Network operators (MNO), commercial banks and other financial institutions, Bank of Uganda, and technology operators. Currently, MNO leads this market at 56\% and has moved into partnerships with BOU supervised financial institutions to ensure safety of customer funds when they are being transferred electronically (Alliance for Financial Inclusion, 2019). Despite efforts to promote online banking through the financial inclusion strategy, several customers are still not comfortable with the internet, have little faith in cashless transactions and have fear that they may lose their money in phishing scams and online frauds. Many customers are seen resistant to the use of E-banking services; hence, the branch services are much necessary too. The threats posed to the customer include identity theft, the risk to private information and sensitive data, and the danger of loss of money due to internet scammers (Sardana \& Singhania, 2018).

\subsection{Statement of the problem}

E-banking has set new heights and drastically influenced consumer behaviour. However, despite a superficially good adoption level, the degree of usage is still low among the customers. Finscope survey 2018 discovered that $73 \%$ of Ugandan Adults accessed their bank account via the bank branches while only $2 \%$ used the internet for similar services. Of these adults, $52 \%$ used bank accounts for saving purposes, $40 \%$ to pay bills and $11 \%$ for credit facilities. Critical to enhance the adoption of digital financial services are consumer data protection, empowerment of users and instilled confidence through awareness and literacy. Again, according to Capgemini (2020), payment volumes are predicted to continue at elevated levels due to the dampened global economy and increased reliance on non-cash transactions. The report also predicts the Compound Annual Growth Rate (CAGR) for non-cash transactions between 2019 and 2023 to be at 12\% having risen from a near surge of 14\% in 2018/2019. There has been increased demand for the internet and a drastic change of consumer behaviour. The year 2019 registered increased non-cash transactions worldwide championed by Asia Pacific that recorded 31.1\% growth. This growth might be attributed to increased use of smartphones, mobile and QR payment systems, digital wallet adoption among others (Capgemini, 2020). Bank of Uganda (2018) acknowledges an increase in the number of transactions for EFTs and RTGS from six million in 2010 to approximately eight million transactions in 2017 and from Ugx 5 billion in 2010 to Ugx 300 billion in 2017 of electronic value.

With online banking, banks could be able to reach unbanked populations, enhance access of financial services to low income, reach geographically distant people and offer social and financial services but adoption to these 
services is still debatable due to perceived risks and costs. However, the adoption rates of online banking are still lower than would be expected. The rate at which people have adapted to mobile money is in fact higher than mobile banking yet the latter offers more advantages such as access to larger loans, interest on savings and access to lengthy statements. Low adoption of internet banking can be evidenced from: 1) customer service desks at the banks have continuously registered complaints about slow web pages that make the transactions slow ending up in error reports. These lead to customer dissatisfaction and low rates of adoption as there will not be registered repeated usage. 2) Banking halls are still packed with queues of people requiring services that could be carried out online. The Monitor newspaper, (2020, January, 11) as detailed by Mr Robert Nyamu the Deloitte's director forensic and litigation support, fraudsters have more recently targeted RTGS systems, EFTs, and point of sale EFTs. This has created fear in the customers who would rather line up in the banking halls than lose huge amounts of money to fraudsters. This could be blamed on the increased bank fraud due toperceived failure to establish high controls that match the increased innovation in the banking sector. Customers might still be hesitant to use online banking because of perceived risks such as loss of money that may end up in wrong transaction accounts. They prefer that if any, such mistakes be made by the bank and its employees so that correction will be made and the customers retain their finances. Max Patrico (2020r 5) reported that Stanbic bank had been hit by online bank fraud where bank accounts falsely instructed the bank to wire money to about 2000 mobile money accounts registered with Airtel and MTN.

Owing to the above, this study sought to identify and examine the most contributing factors to online banking adoption rates among individual bank customers in Kampala, Uganda. The study delimits itself to the relevance of perceived usefulness (PU), perceived ease of use (PEOU), perceived risk (PR) and customer satisfaction (CS) in regard to the adoption of online banking technology in 3 out of 26 commercial banks (Standard Chartered Bank, Centenary Bank, and Stanbic Bank) with branches in Kampala. The study specifically intended to:

i) To evaluate the factors that affect adoption of internet banking among customers in Kampala, Uganda.

ii) To analyse the relationship between adoption of internet banking and its contributing factors

iii) To establish the role of customer satisfaction in relation to the adoption of internet banking in Uganda

iv) To establish the mediating effects of customer satisfaction in a relationship of the determining factors of online banking adoption

This research makes a contribution by adding knowledge value to the theory and limited literature available about the banking sector in Uganda and sub-Saharan Africa in general. Specifically, the study offers solutions to the bankers and several other financial institutions in Uganda on how to enhance online banking adoption amidst rapid customer behavioural changes towards brick and mortar service delivery and therefore require rapid technological changes to cope with the market transition. The rest of the paper presents the literature review, the study methodology, the discussion of findings of the study and the conclusions and recommendations.

\subsection{Theoretical Framework}

Roger (1963) under the diffusion of innovation theory contends that culture determines the spread of technology and innovation, and it is based on the fact that several people possess different qualities and may therefore accept or reject innovation (Anyona, 2018). This means that customer adoption frequency can be modelled into a classical bell-shaped distribution curve (Achieng \& Ingari, 2015). Innovation here is the extent to which individuals adopt to the system compared to others (Rogers, 1983; Achieng \& Ingari, 2015) with a five-category classification of innovators, early adopters, early majority, late majority and laggards. In this order, innovators that form 2.5 percent will always be the most versatile, inquisitive and creative compared to the rest of the categories as they are willing to take on more risks and are more daring. Ideally, such adopters have the ability to observe, have relative advantage, ability to try out complex issues (Kiura, 2018).

Additionally, Davis, Bagozzi, and Warshaw (1989) provide the Technology Acceptance Model (TAM). This model suggests perceived usefulness and perceived ease of use as the most important factors that readily explain consumer behaviour towards adoption (Davis, 1989; Anyona, 2018). Davis explains that intention to use determines actual behaviour which influences attitude and the perceived usefulness. These in turn are based on perceived ease of use. TAM argues that external variables that support ease of use and advantages of adoption are very vital to technology because other factors being constant, an easy to use system offers wide benefits to the user. The extended model of the technology acceptance model added variables such as risk, trust and cost to determine the consistency of the research results (Venkatesh et al. 2003). In fact, Makanyeza (2017) urges banks to concentrate on TAM when designing new mobile bank services as this model determines consumers' intention to adopt mobile banking services in the same way that Lin, Wang and Hung, (2020) does. This study therefore makes more contribution towards the Technology Acceptance Model and diffusion of innovation theory. 


\section{Figure 1: Conceptual framework}

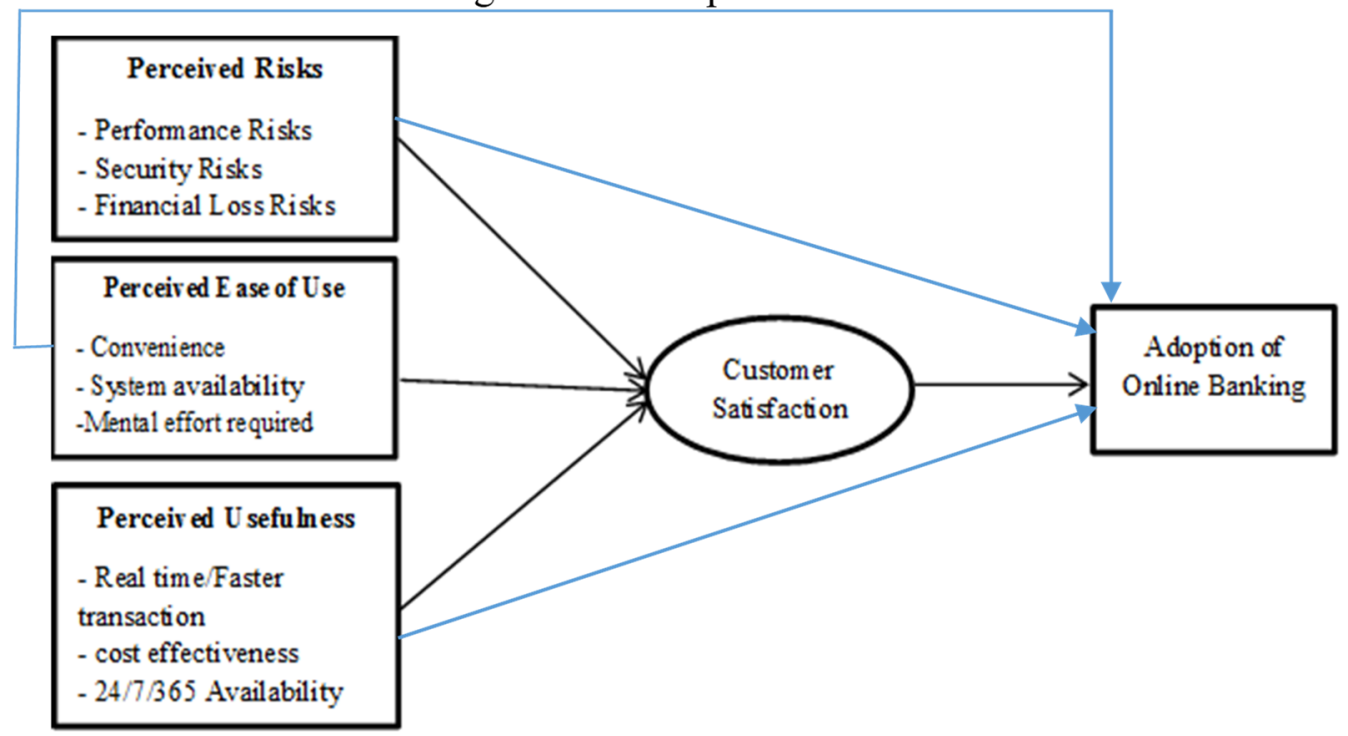

Source: Extant literature review

\section{Literature review}

\subsection{Perceived risk (PR) and online banking adoption}

Risk perceptions are by far the most influential barrier towards adoption of internet banking as customers perceive online banking to be riskier than conventional banking (Tsanga, 2018). Perceived risk refers to a "spirit cost associated with uncertainty in the future that directly affects consumers' intention to purchase" (Wei, Wang, Zhu, Xue, \& Chen, 2018; Zhang \& Yu, 2020; Zhang, Lu, \& Kizildag, 2018). Bauer (1960) who introduced perceived risk to consumer behavioural analysis noted that perceived risk is brought about by lack of product information. While critiquing the works of Tan and Teo (2000) and Brown et al. (2003) who modelled perceived risk as a single construct, Lee (2009) expanded on the variable to encompass 5 facets. These facets include performance risks, security/privacy risks, time/convenience risks, social risks and financial risks. Performance risks are losses that can be experienced due to deficiencies or malfunctions of mobile servers, expected to reduce customers' willingness to use internet banking. Security risks on the other hand consider potential losses arising from fraud or compromise of the security system of an online banker by a hacker. The other looks at any inconvenience or loss of time arising from the difficulty or failure to navigate the site or even receive a payment requested, difficulty in finding the right website application to use uploads and downloads on a bank page. The social or psychological risk would occur if the social circles of a customer like friends, family and work-group disapprove of the use of online banking, bringing negative decisions made by the customer to the adoption of online banking. Lastly, financial risks may arise out of distrust for the system functions, fear of being overcharged, fear that the purchased product may not fulfil the purpose for which they were bought and the general internet insecurity. These risks represent potential monetary losses owing to transaction errors or bank account misuse (Lee, 2009). All these constructs impact negatively on the adoption of online banking.

\subsection{Perceived ease of Use (PEOU) and online banking adoption}

Davis (1989) define perceived ease of use as the level at which a person believes that little effort is needed to be able to use a particular system with a high degree of certainty so as to improve their work performance. This certainly drives consumers towards the use of new technology based applications to run their financial transactions. Moreover, according to Roy and Sinha (2017) perceived ease of use can considerably influence the adoption of online banking. It influences the attitude towards the system which in turn influences the behavioural intention of the customer which directly affects the actual use (Lin, Wang, \& Hung, 2020). This therefore implies that banking institutions might increase online banking adoption rates among their customers if they design systems that are easy to operate (Achieng \& Ingari, 2015).

\subsection{Perceived usefulness (PU) and online banking adoption}

David (1989) describes perceived usefulness to be confidence initiated by an individual that its adoption of an activity will have a positive impact and would as a result increase their performance. Many customers have therefore appreciated the ease of use, reliability, abundance of information and cost reductions which are important to the success of internet banking (Cai, Yang, \& Cude, 2008). Usefulness is determined by the following 
characteristics; relative advantage, website quality, knowledge and support. With relative advantage, online bankers are more likely to access a wide variety and amount of information, 24/7 accessibility compared to nonusers (Cai et al., 2008). Moreover, they will be saving money and time. Website quality conversely supports the banks by offering traditional services and highlighting new opportunities that arise from the internet being a new channel to conduct business (Swaid \& Wigand, 2007). Banks are therefore encouraged to design their websites putting emphasis on screen designs, navigation patterns strategically to enhance usability and usefulness (Floh \& Treblamarer, 2006) as customers might be impatient with delays. Lastly, considering knowledge and support, the lack of knowledge about financial services may negatively affect individuals' decisions as well as consumer usage. Consumers need the type and amount of information as availed by customer service personnel in the banking halls. But even most importantly, the customer service personnel should have adequate information as regards how the bank website works, how customers can register for online services and what perquisites they may be taking if they sign up. A number of studies corroborate the positive effect of perceived usefulness on customers' adoption of online banking (Akinyemi et al., 2013; Yitbarek \& Zaleke, 2013; Al-Smadi, 2012).

\subsection{Customer satisfaction (CS) and adoption of online banking as a mediator}

Customer satisfaction denotes a person's feeling of pleasure or disappointment, which resulted from comparing a product's perceived performance or outcome against his/her expectations (Asiyanbi \& Ishola, 2018). Asiyanbi \& Ishola's (2018) study highlight among others service quality, security and privacy as highly vital to customer satisfaction since they have a positive effect and determine customers' purchasing intentions and relationship with the bank. While customers look for satisfaction, the usually opt for portability versus reliability when choosing a platform to access internet services (Al-Khalaf \& Choe, 2020) even when it can be reasoned that reliability possesses the utmost essential features of internet banking. Customer satisfaction and quality are very parallel in the banking sector most especially because banking is in the service industry (Pooya, Khorasani \& Ghouzdhi, 2020; Tseng \& Wei, 2020). Accordingly, quality is measured by the consumer who might appreciate quality of service beyond quality of information or quality of the system (Fornelle, 1992).

\subsection{Research methodology}

A cross sectional research design was employed in this study to achieve the study aims and objectives. Quantitative approach was employed through the use of a survey questionnaire. Quantitative indicators and hypotheses were identified and structured into a questionnaire. The self-administered questionnaire consisted of two sections. The first captured demographic information about respondents that included personal data and experiences they have had with online banking. The second section used a five-point likert scale to survey respondents' perceptions towards the dependent variables. The study was carried out in Kampala, the capital city of Uganda specifically with customers of Centenary bank - Mapeera House, Standard Chartered Bank Nile Avenue and Stanbic Bank Crested Towers which are all around the Central Business District.

The target population consisted of customers of the headquarters of the three banks since these were the biggest branches with the most numbers of customers. All banks offer both in store and online services and respondents were account holders with personal, business or corporate accounts and either Savings, current or fixed accounts. This study used simple random strategy and purposive sampling method to identify the customers as they are the key subjects of study in online banking. The respondents' knowledge and experiences were important to this study as they are key in online banking adoption. Krejcie and Morgan (1970) sample size determination table was used to get a sample of 310 customers out of which only 300 responded to the study questionnaires representing $96.77 \%$ response rate. Primary data such as demographics, motivations, attitudes and lifestyle characteristics were collected using questionnaires with guidance from Anyola (2018), Achieng \& Ingari (2015), Karma, Ibrahim \& Ali (2014) and Kabir (2013). To increase the quality of primary data, questionnaire respondents were guaranteed confidentiality and anonymity and given a brief before they started filling out questionnaires. The questions were also precise and concise making them easy to understand and respond to. This led to increased response rates and ensured quality of data collected.

Once survey questionnaires were collected, they were checked for completeness, accuracy and review to screen out incomplete, redundant and ambiguous responses. The remaining information was then transformed into research terms. A Microsoft excel sheet was then drawn and a thorough collection of responses presented through tables, percentages, standard deviation and mean. These provided a summary of answers from the questionnaire and answered the research questions. The excel sheet data was then imported into and analysed using a statistical package for social scientists (SPSS) version 23. Content validity index (CVI) (Stephanie, 2016) to measure the validity of the instrument given to 10 experts to give their expert view on whether the questionnaire would capture the intended data. All responses gave a CVI of over 0.8 . The aggregate Cronbach alpha test computation was done for reliability of questions for the study from a pre-test on 30 respondents before the actual survey. A Cronbach alpha coefficient of 0.770 was achieved for the 26 items which was a satisfactory level of internal consistency of the scale. Descriptive statistics were computed and thereafter correlation and regression tests were conducted for 
the study. The study model specification went as follows for the inferential tests:

$\mathrm{LOA}=\beta 0+\beta 1 \mathrm{X} 1+\beta 2 \mathrm{X} 2+\beta 3 \mathrm{X} 3+\varepsilon$

Where;

LOA $=$ Level of Adoption of online banking

$\beta 0=$ constant

$\mathrm{X} 1=$ Perceived Risks $(\mathrm{PR})$

$\mathrm{X} 2=$ Perceived Ease of Use $(\mathrm{PEOU})$

$\mathrm{X} 3$ = Perceived Usefulness (PU)

$\mathrm{X} 4=$ Customer Satisfaction (CS)

$\varepsilon=$ Error margin

\section{Findings}

310 questionnaires were distributed to customers of Centenary, Stanbic and standard chartered banks. A response rate of $96.77 \%$ was registered as 300 questionnaires were properly filled and returned. These were the basis of this study analyses that follow.

4.1 Demographic characteristics

Table 4.1: Gender of respondents

\begin{tabular}{|l|l|l|l|}
\hline Variable & Classification & Frequency & Percentage (\%) \\
\hline Gender & Male & 126 & 42 \\
\hline & Female & 174 & 58 \\
\hline & Total response & 300 & 100 \\
\hline Age of respondents & $18-30$ & 98 & 32.67 \\
\hline & $31-40$ & 125 & 41.67 \\
\hline & $41-50$ & 46 & 15.33 \\
\hline & 50 and above & 31 & 10.33 \\
\hline & Total response & 300 & 100 \\
\hline
\end{tabular}

\section{Source: Primary Data}

The findings in table 4.1 first, on gender indicate that majority respondents were female (58\%) with $42 \%$ male and both genders were fairly represented. Second, majority of respondents on were aged between 31 and 40 years $(41.67 \%)$ followed by $32.67 \%$ who were between the ages 18 and 30 years. The rest of the respondents were between the age of 41 and 50 years representing $15.33 \%$ and the last category of respondents of 50 years and above represented $10.33 \%$. Therefore, there was fair representation as the views of the entire population regardless of age was reflected though most of the commercial banks seem to serve more youthful and middle-aged customers.

Regarding the Level of Education and where the respondents get their banking services from, table 4.2 below provides a clear description.

Table 4.2: Level of education and bank services

\begin{tabular}{|l|l|l|l|}
\hline Variable & Classification & Frequency & Percentage(\%) \\
\hline Education Qualification & Certificate & 7 & 2.3 \\
\hline & Diploma & 36 & 12 \\
\hline & Degree & 176 & 58.7 \\
\hline & Masters & 81 & 27 \\
\hline Bank Services & Total response & 300 & 100 \\
\hline & Centenary & 93 & 31.0 \\
\hline & Standard chartered & 104 & 34.7 \\
\hline & Stanbic & 103 & 34.3 \\
\hline & Total response & 300 & 100.0 \\
\hline
\end{tabular}

Source: Primary Data

Results in table 4.2 indicate that most of the respondents had a first degree as the highest level of education $(58.7 \%)$. The second largest number was those with master's degree or above as a qualification represented by $27 \%$ followed by diploma holders $(12 \%)$ and lastly certificate holders represented by $2.3 \%$. Therefore, the level of education was diverse and relatively represented. This could also attest to the level at which the questionnaire questions and hence the research questions were understood and answered to the best of knowledge of the respondents. Averagely, respondents showed they get their banking services from any of the three banks under study. Most successful questionnaires returned were those from Standard Chartered bank at a rate of $34.7 \%$ followed by Stanbic at $34.3 \%$ then Centenary at 31.0\%. All banks were relatively well represented in the survey as respondents are their actual customers.

Table 4.3 below shows the type of account the held by respondents and how often they use e-banking with 
their bankers. With the banking diversity, majority of respondents (91\%) hold personal accounts and a few (7\%) have business accounts and the least $(2 \%)$ run corporate accounts with the banks under study. This shows that most people with bank accounts are actually keeping their personal funds and therefore any mishap or credit that may be borne by the account is also borne by the individual.

Table 4.3 Type of account respondents hold and use of online banking

\begin{tabular}{|l|l|l|l|}
\hline Variable & Classification & Frequency & Percentage(\%) \\
\hline Type of account & Personal & 273 & 91.0 \\
\hline & Corporate & 21 & 7.0 \\
\hline & Business & 6 & 2.0 \\
\hline & Total response & 300 & 100.0 \\
\hline How often they use online-banking & Never & 77 & 25.7 \\
\hline & Rarely & 100 & 33.3 \\
\hline & Sometimes & 77 & 25.7 \\
\hline & Usually & 30 & 10.0 \\
\hline & Often & 16 & 5.3 \\
\hline & Total response & 300 & 100.0 \\
\hline
\end{tabular}

\section{Source: Primary data}

When asked how often they use online banking, the majority of the respondents $(33.3 \%)$ indicated they rarely used it, others never $(25.7 \%)$, sometimes $(25.7 \%)$, usually $(10.0 \%)$ and very few often $(5.3 \%)$. This shows that the number of respondents using internet banking often is a very small number out of the entire population.

4.1.1 Benefits of using online banking hence adoption.

To establish the benefits associated with online banking, a likert scale was engaged to enable respondents attach the level at which they value these benefits. The findings in table 4.4 below show majority of respondents to strongly agree to using online banking to check bank details. The mean response was 4.23 and standard deviation 1.068 indicating that the responses were varied. Most respondents also agreed to using their online accounts to check on mini statements at a mean of 4.16 and a standard deviation of 0.927 to show that responses were not varied.

Table 4.4 Showing Benefits of using online banking

\begin{tabular}{|l|l|l|l|l|l|l|l|l|}
\hline & & $\mathrm{SD}$ & $\mathrm{D}$ & $\mathrm{N}$ & $\mathrm{A}$ & $\mathrm{SA}$ & Mean & SD \\
\hline Account details & Frequency & 15 & 12 & 18 & 99 & 156 & 4.23 & 1.068 \\
\hline & $\%$ & 5.0 & 4.0 & 6.0 & 33.0 & 52.0 & & \\
\hline Mini statement & Frequency & 10 & 8 & 24 & 139 & 119 & 4.16 & 0.927 \\
\hline & $\%$ & 3.3 & 2.7 & 8.0 & 46.3 & 39.7 & & \\
\hline Forex & Frequency & 7 & 9 & 21 & 100 & 163 & 4.34 & 0.910 \\
\hline & $\%$ & 2.3 & 3.0 & 7.0 & 33.3 & 54.3 & & \\
\hline Bills \& utilities & Frequency & 5 & 9 & 21 & 108 & 157 & 4.34 & 0.865 \\
\hline & $\%$ & 1.7 & 3.0 & 7.0 & 36.0 & 52.3 & & \\
\hline Transfer funds & Frequency & 147 & 79 & 39 & 21 & 14 & 1.92 & 1.148 \\
\hline & $\%$ & 49.0 & 26.3 & 13.0 & 7.0 & 4.7 & & \\
\hline Credit \& loans & Frequency & 83 & 39 & 45 & 62 & 71 & 3.00 & 1.549 \\
\hline & $\%$ & 27.7 & 13.0 & 15.0 & 20.7 & 23.7 & & \\
\hline Real time services & Frequency & 9 & 23 & 12 & 116 & 140 & 4.18 & 1.026 \\
\hline & $\%$ & 3.0 & 7.7 & 4.0 & 38.7 & 46.7 & & \\
\hline 24/7/365 days & Frequency & 8 & 18 & 22 & 85 & 167 & 4.28 & 1.016 \\
\hline & $\%$ & 2.7 & 6.0 & 7.3 & 28.3 & 55.7 & & \\
\hline Average & & & & & & & 3.80 & 1.063 \\
\hline
\end{tabular}

Source: Primary data

Several respondents use online accounts to check for foreign exchange rates as $54.3 \%$ strongly agreed to the statement. The question recorded a mean of 4.34 and a standard deviation of 0.910 to show that responses were not varied. When asked if online banking was beneficial for paying utilities and bills, majority strongly agreed at a $52.3 \%$ frequency, 4.34 mean and 0.865 standard deviation to show that responses were not varied. As regards using online platform to transfer funds, most respondents (49\%) strongly disagreed to using the platform for these purposes. The mean was 1.92 and responses varied at a standard deviation of 1.148. For the purposes of credit card and loan payments, respondents strongly disagreed $(27.7 \%)$ to benefit from online-banking this way. The mean was 3.00 and responses varied quite a bit as the standard deviation was 1.549. Most respondents (46.7\%) strongly agreed that online bank services provided real time services with a mean of 4.18 and standard deviation of 1.026 to show that responses varied among the respondents. $55.7 \%$ of the respondents strongly agreed that internet banking provided 24 hour services 7 days a week throughout the 365 days in a year. Therefore, internet banking 
was constantly available. The mean was 4.28 and standard deviation 1.016.

\subsection{Testing variables.}

\subsubsection{Perceived risk of online banking}

The study enquired about the perceived risk of online banking among the adults who have a traditional bank account with centenary bank, standard chartered bank and Stanbic bank around Kampala with responses rated on a five-point Likert scale ranging from strongly disagree (SD) to strongly agree (SA) and the results are presented in table 4.5 below. Most of the respondents (46.7\%) strongly agreed with the statement that the online banking was expensive to use. The mean for the statement was 3.80 and standard deviation was 1.43 implying a high variation in responses.

Table 4.5: Results of showing perceived risks of online banking

\begin{tabular}{|l|l|l|l|l|l|l|l|l|}
\hline & & $\mathrm{SD}$ & $\mathrm{D}$ & $\mathrm{N}$ & $\mathrm{A}$ & $\mathrm{SA}$ & Mean & SD \\
\hline Expensive to use & Frequency & 41 & 23 & 30 & 66 & 140 & 3.80 & 1.439 \\
\hline & $\%$ & 13.7 & 7.7 & 10.0 & 22.0 & 46.7 & & \\
\hline Secure to send sensitive info & Frequency & 252 & 33 & 9 & 6 & 300 & 1.39 & 0.939 \\
\hline & $\%$ & 84.0 & 11.0 & 3.0 & 2.0 & 100.0 & & \\
\hline Convenient \& saves time & Frequency & 15 & 25 & 53 & 138 & 69 & 3.74 & 1.060 \\
\hline & $\%$ & 5.0 & 8.3 & 17.7 & 46.0 & 23.0 & & \\
\hline Risky to use & Frequency & 6 & 18 & 53 & 223 & 300 & 4.56 & 0.921 \\
\hline & $\%$ & 2.0 & 6.0 & 17.7 & 74.3 & 100.0 & & \\
\hline There may be loss of money & Frequency & 3 & 6 & 36 & 102 & 153 & 4.32 & 0.837 \\
\hline & $\%$ & 1.0 & 2.0 & 12.0 & 34.0 & 51.0 & & \\
\hline Satisfied with verification & Frequency & 177 & 32 & 55 & 23 & 13 & 1.88 & 1.208 \\
\hline & $\%$ & 59.0 & 10.7 & 18.3 & 7.7 & 4.3 & & \\
\hline Average & & & & & & & 2.658 & 1.067 \\
\hline
\end{tabular}

Source: Primary data

Majority of the respondents $252(84 \%)$ strongly disagreed with the statement that mobile banking platform was a secure place through which to send sensitive information indicating a perceived risk in online banking. The mean response was 1.39 , indicating that most of the respondents did not agree with the statement, while the standard deviation of 0.939 indicated a minimal variance in responses. Furthermore, approximately $46 \%$ of the respondents agreed with the statement that they find online banking to be convenient and saves time. The mean response to the statement was 3.74 showing that majority of the respondents agreed with that particular statement. The standard deviation was 1.060 . About $74.3 \%$ of the respondents also agreed that online banking is risky to use, directly increasing the perceived risk in this mode of banking. The mean response for the statement was 4.56 , meaning that majority of the respondents strongly agreed with the information. The standard deviation was 0.921 showing less variation in responses. When asked if they were satisfied with the verification process of online users, the respondents $(59.0 \%)$ strongly disagreed. The mean for this statement was 1.88 as several responses disagreed with the statement and standard deviation 1.208 because responses slightly varied.

4.2.2 Perceived Ease of Use of online banking

The second independent variable tested was perceived ease of use of online banking among customers. The responses were evaluated on the same Likert scale and the results presented in table 4.6 below as follows; The majority, $70.0 \%$ of the respondents strongly agreed with only $2.0 \%$ strongly disagreeing that they can access their bank account on internet devices such as phones, tablets and computers. The mean for the statement is 4.45 while the standard deviation was 0.019 showing that responses were not varied. Additionally, $49.3 \%$ of the respondents strongly disagreed with the idea that internet banking is complicated and difficult to use. Only $9.0 \%$ thought it was. The mean for this variable was 2.18 and standard deviation 1.394 . The study also established that $55.7 \%$ of the respondents strongly agreed with the statement that interaction with online banking services did not require a lot of mental effort. Their mean was 4.06 while the standard deviation was 1.248 . this was almost similar where $55.7 \%$ respondents found online banking procedures flexible to interact with, which registered a mean of 4.12 and standard deviation of 1.207 . 
Table 4.6: Results showing perceived ease of use of online banking

\begin{tabular}{|l|l|l|l|l|l|l|l|l|}
\hline & & SD & D & N & A & SA & Mean & SD \\
\hline Access on devices & Frequency & 6 & 25 & 7 & 52 & 210 & 4.45 & 0.019 \\
\hline & $\%$ & 2.0 & 8.3 & 2.3 & 17.3 & 70.0 & & \\
\hline Complicated \& difficult & Frequency & 148 & 42 & 44 & 39 & 27 & 2.18 & 1.394 \\
\hline & $\%$ & 49.3 & 14.0 & 14.7 & 13.0 & 9.0 & & \\
\hline Doesn't require mental effort & Frequency & 11 & 42 & 33 & 47 & 167 & 4.06 & 1.248 \\
\hline & $\%$ & 3.7 & 14.0 & 11.0 & 15.7 & 55.7 & & \\
\hline Flexible to interact with & Frequency & 13 & 32 & 28 & 60 & 167 & 4.12 & 1.207 \\
\hline & $\%$ & 4.3 & 10.7 & 9.3 & 20.0 & 55.7 & & \\
\hline Easy \& quick to learn & Frequency & 6 & 34 & 28 & 86 & 146 & 4.11 & 1.098 \\
\hline & $\%$ & 2.0 & 11.3 & 9.3 & 28.7 & 48.7 & & \\
\hline Apps are clear \& understandable & Frequency & 24 & 43 & 45 & 73 & 115 & 3.71 & 1.322 \\
\hline & $\%$ & 8.0 & 14.3 & 15.0 & 24.3 & 38.3 & & \\
\hline Average & & & & & & & 3.77 & 1.048 \\
\hline
\end{tabular}

Source: Primary data

In regards to the question 'learning to operate online banking is easy and quick', most people (48.7\%) strongly agreed and only $2.0 \%$ strongly disagreed. The standard deviation was varied at 1.098 . As to whether the bank websites and apps are appealing, clear and easy to understand, majority of the respondents (62.6\%) agreed while $15 \%$ were not sure and the rest disagreed, with mean of 3.71 and standard deviation of 1.322 .

4.2.3 Perceived usefulness of online banking

Table 4.7 below shows results of perceived usefulness of online banking among bank customers as rated on a Likert scale. When asked if they thought mobile banking helped them accomplish tasks faster, majority respondents, $45.3 \%$ strongly agreed with mean of 4.01 standard deviation of 1.185 . Similarly, the results indicate that majority $(49.7 \%)$ of the respondents strongly agreed with the fact that online banking makes it easier to carry out tasks with mean of 4.09 and standard deviation of 1.160 .

Table 4.7: Results showing perceived usefulness of online banking

\begin{tabular}{|l|l|l|l|l|l|l|l|l|}
\hline & & $\mathrm{SD}$ & $\mathrm{D}$ & $\mathrm{N}$ & $\mathrm{A}$ & $\mathrm{SA}$ & Mean & SD \\
\hline Accomplish tasks faster & Frequency & 15 & 30 & 29 & 90 & 136 & 4.01 & 1.185 \\
\hline & $\%$ & 5.0 & 10.0 & 9.7 & 30.0 & 45.3 & & \\
\hline Easy to carry out tasks & Frequency & 13 & 28 & 27 & 83 & 149 & 4.09 & 1.160 \\
\hline & $\%$ & 4.3 & 9.3 & 9.0 & 27.7 & 49.7 & & \\
\hline Improves self-image \& prestige & Frequency & 11 & 15 & 31 & 86 & 157 & 4.21 & 1.057 \\
\hline & $\%$ & 3.7 & 5.0 & 10.3 & 28.7 & 52.3 & & \\
\hline Trendy \& savvy & Frequency & 10 & 17 & 28 & 87 & 158 & 4.22 & 1.050 \\
\hline & $\%$ & 3.3 & 5.7 & 9.3 & 29.0 & 52.7 & & \\
\hline Offers more information & Frequency & 9 & 16 & 28 & 167 & 80 & 3.98 & 0.920 \\
\hline & $\%$ & 3.0 & 5.3 & 9.3 & 55.7 & 26.7 & & \\
\hline Overall advantageous & Frequency & 4 & 11 & 10 & 101 & 174 & 4.43 & 0.833 \\
\hline & $\%$ & 1.3 & 3.7 & 3.3 & 33.7 & 58.0 & & \\
\hline Average & & & & & & & 4.15 & 1.034 \\
\hline
\end{tabular}

\section{Source: Primary data}

Several respondents $(81 \%)$ agreed that using online payment improved their self-esteem and prestige and therefore was useful in regard to their social influence, with mean of 4.21 and standard deviation of 1.057. This implies that online payment agreed is useful albeit some variation in responses. Similarly, $81.7 \%$ of respondents agreed that mobile banking made them look trendy and savvy among peers hence increasing their social appearance and capital with mean of 4.22 and standard deviation 1.050, showing slight variation in responses. Mobile banking was agreed to offer a wider range of information than the traditional banking hall system as most respondents $82.4 \%$ agreed overall to this statement at a mean of 3.98 and standard deviation of 0.920 to show that results were not varied. As to whether online banking is advantageous overall, respondents $58.0 \%$ strongly agreed and $33.7 \%$ agreed with mean of 4.43 and standard deviation of 0.833 , hence responses were not greatly varied. All these responses reflect usefulness of online banking to customers.

4.2.4 Results of customer satisfaction with mobile/online banking

The results in table 4.8 below show the study sought to establish the effect of demographics among bank account holders on the five-point Likert scale. Most responses (49\%) disagreed that they preferred internet banking with mean of 2.62 and varied responses at a standard deviation of 1.244. This could be attributed to the fact that majority respondents $(51.7 \%)$ strongly agreed that they would be criticized if they lost money due to errors within online banking at a mean of 4.31 with responses that did not vary at a standard deviation of 0.919 . 
Table 4.8: Results of level of satisfaction

\begin{tabular}{|l|l|l|l|l|l|l|l|l|}
\hline & & $\mathrm{SD}$ & $\mathrm{D}$ & $\mathrm{N}$ & $\mathrm{A}$ & $\mathrm{SA}$ & Mean & SD \\
\hline Prefer mobile banking & Frequency & 43 & 147 & 25 & 51 & 34 & 2.62 & 1.244 \\
\hline Criticism for loss of money & $\%$ & 14.3 & 49.0 & 8.3 & 17.0 & 11.3 & & \\
\hline & Frequency & 6 & 15 & 13 & 111 & 155 & 4.31 & 0.919 \\
\hline Age doesn't affect & $\%$ & 2.0 & 5.0 & 4.3 & 37.0 & 51.7 & & \\
\hline & Frequency & 12 & 33 & 17 & 170 & 68 & 3.83 & 1.029 \\
\hline Education level affects & $\%$ & 4.0 & 11.0 & 5.7 & 56.7 & 22.7 & & \\
\hline & Frequency & 53 & 144 & 24 & 58 & 21 & 2.50 & 1.189 \\
\hline Intend to continue use & $\%$ & 17.7 & 48.0 & 8.0 & 19.3 & 7.0 & & \\
\hline & Frequency & 23 & 46 & 42 & 104 & 85 & 3.61 & 1.256 \\
\hline Would recommend online banking & Frequency & 15 & 41 & 75 & 104 & 65 & 3.54 & 1.122 \\
\hline & $\%$ & 5.0 & 13.7 & 25.0 & 34.7 & 21.7 & & \\
\hline
\end{tabular}

Source: Primary data

Overall, majority of the respondents $(79.4 \%)$ agreed that age does not affect their ability to operate online banking at a mean of 3.8 and standard deviation of 1.029 showing that responses were slightly varied. When asked about education level, most respondents $(65.7 \%)$ disagreed overall that education levels did affect their usage capacity of online banking at a mean of 2.25 with varied responses at 1.189 standard deviation. Most respondents $(63 \%)$ also agreed overall that they will continue using mobile banking services with varied responses at mean 3.61 and standard deviation of 1.256. They also agreed to recommend online banking with majority responses totaling to $56.4 \%$ agreeing with mean of 3.54 and standard deviation 1.122 . These responses show that bank customers are satisfied with online banking.

\subsection{Inferential statistics}

Table 4.9 Test for multi-collinearity

\begin{tabular}{lll} 
Variable & Tolerance & Variance Inflation Factor (VIF) \\
\hline PU & .843 & 1.187 \\
\hline PEOU & .870 & 1.149 \\
\hline PR & .964 & 1.037 \\
\hline CS & .902 & 1.112 \\
\hline ADOPTION & .899 & 1.106 \\
\hline
\end{tabular}

Source: Primary Data

The tolerance values for all variables is greater than 0.1 . Therefore, there is no problem of multi-collinearity among them and hence reliable.

4.3.1 Correlation Analysis

Table 4.10: Pearson correlation matrix

\begin{tabular}{llllllll}
\hline & & ADOPTION & PU & PEOU & PR & Mean & SD \\
\hline ADOPTION & Pearson Correlation & 1 & $.341^{* *}$ & .104 & $.279^{* *}$ & 3.807 & 0.630 \\
\cline { 2 - 7 } & Sig. (2-tailed) & & .000 & .071 & .000 & & \\
\cline { 2 - 7 } & $\mathrm{N}$ & 300 & 300 & 300 & 300 & & \\
\hline \multirow{2}{*}{ PEOU } & Pearson Correlation & $.341^{* *}$ & 1 & $.355^{* *}$ & $.179^{* *}$ & 4.157 & 0.710 \\
\cline { 2 - 7 } & Sig. (2-tailed) & .000 & & .000 & .002 & & \\
\hline & $\mathrm{N}$ & 300 & 300 & 300 & 300 & & \\
\hline \multirow{2}{*}{ PR } & Pearson Correlation & .104 & $.355^{* *}$ & 1 & .007 & 3.7706 & 0.669 \\
\hline & Sig. (2-tailed) & .071 & .000 & & .909 & & \\
\hline & $\mathrm{N}$ & 300 & 300 & 300 & 300 & & \\
\hline & Pearson Correlation & $.279^{* *}$ & $.179^{* *}$ & .007 & 1 & 3.281 & 0.480 \\
\hline & Sig. (2-tailed) & .000 & .002 & .909 & & & \\
\hline
\end{tabular}

**. Correlation is significant at the 0.01 level (2-tailed).

The direction of relationship and significance between variables was established by correlation analysis. The results showed that adoption of mobile banking is positively correlated with the three independent variables. The results show that adoption is positively and significantly associated with PU at $(r=0.341, p<0.001)$. With PEOU, adoption of mobile banking is positively correlated at $(r=0.104, p=0.071)$ though it does not show any significant relationship. Adoption is positively correlated to PU $(r=0.279, p<0.001)$. Therefore, any improvements in the independent factors mean an improvement in the level of adoption and vice versa. The study also indicates that 
PU and PEOU, are positively and significantly correlated with each other $(r=0.355, p=0.001)$, PU and PR are also positively and significantly correlated with each other $(r=0.104, p=0.002)$. PEOU and PR are positively associated though not significant according to results $(r=0.007, p=0.909)$.

Table 4.11: Testing for fitness of model and significance

\begin{tabular}{|l|l|l|l|l|l|l|}
\hline \multicolumn{2}{|l|}{ ANOVA } \\
\hline Model & Sum of Squares & df & Mean Square & F & Sig. \\
\hline \multirow{2}{*}{1} & Regression & 19.636 & 3 & 6.545 & 19.540 & $.001^{\mathrm{b}}$ \\
\cline { 2 - 7 } & Residual & 99.154 & 296 & .335 & & \\
\cline { 2 - 7 } & Total & 118.791 & 299 & & & \\
\hline
\end{tabular}

a. Dependent Variable: ADOPTION

b. Predictors: (Constant), PR, PEOU, PU

ANOVA is utilised to establish the fitness of the model and justify the significance of the relationship between adoption of online banking and the independent variables herein. Findings show a significant relationship between the dependent and independent variables given the level of significance 0.001 which is below $p$-value of 0.05 . Therefore, the model was a reasonable fit that had a significant association between adoption of online banking and selected independent variables.

4.3.2 Regression analysis

Regression analysis was undertaken to identify the nature of the relationships that exist between the study variables. The standardized coefficients represent a change in the adoption levels of online banking due to one unit change in each independent variable, other factors held constant as can be seen in the results table 4.12 below.

Table 4.12: Regression coefficient results

\begin{tabular}{|c|c|c|c|c|c|c|}
\hline \multirow{2}{*}{\multicolumn{2}{|c|}{ Model }} & \multicolumn{2}{|c|}{$\begin{array}{l}\text { Unstandardized } \\
\text { Coefficients }\end{array}$} & \multirow{2}{*}{$\begin{array}{l}\text { Standardized } \\
\text { Coefficients } \\
\text { Beta } \\
\end{array}$} & \multirow[b]{2}{*}{$\mathrm{t}$} & \multirow[b]{2}{*}{ Sig. } \\
\hline & & B & Std. Error & & & \\
\hline \multirow[t]{4}{*}{1} & (Constant) & 1.741 & .312 & & 5.573 & .001 \\
\hline & PU & .268 & .051 & .302 & 5.218 & .001 \\
\hline & PEOU & -.004 & .054 & -.004 & -.075 & .940 \\
\hline & PR & .295 & .071 & .225 & 4.166 & .001 \\
\hline
\end{tabular}

\section{Source: Primary Data}

Results show that PU is positively and significantly related with adoption of online banking among the banks' customers $(\beta=0.302, p=0.001)$. A unit increase in PU translates to 0.302 increases in adoption and therefore PU positively affects adoption of online banking. Relatedly, PR positively and significantly influences online banking adoption $(\beta=0.225, p=0.001)$. this means that a unit increase in PR leads to 0.225 increase in adoption levels other factors in the model held constant. However, PEOU did not show any tangible and significant relationship with online banking adoption $(\beta=-0.004, p=0.940)$.

For The model LOA $=\beta 0+\beta 1 \mathrm{PU}+\beta 2 \mathrm{PEOU}+\beta 3 \mathrm{PR}+\varepsilon$ therefore shows that all other variables have a value of zero when adoption level is at 1.741 .

Table 4.13 Model summary of the regression analysis

\begin{tabular}{|l|l|l|l|l|}
\hline & & & & \\
Model & $\mathrm{R}$ & $\mathrm{R}$ Square & Adjusted R Square & Std. Error of the Estimate \\
\hline 1 & $.407^{\mathrm{a}}$ & .165 & .157 & .57878 \\
\hline
\end{tabular}

a) Predictors: (Constant), PR, PEOU, PU

b) Dependent Variable: Adoption

4.3.3 Customer satisfaction as a mediating factor

The mediating effects of satisfaction was first tested against perceived use (PU) and the results are presented in table 4.14 . 
Table 4.14: Satisfaction mediating perceived use (PU) and adoption of online banking $\mathrm{Y}=\mathrm{ADOPTION}, \mathrm{X}=\mathrm{PU}, \mathrm{M}=\mathrm{SATISFY}$

Model Summary

$\mathrm{R}$

$$
.3672
$$
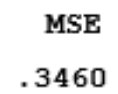

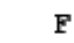

23.1412 df1

2. 0000 df2

297.0000

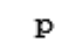

.0000

Model

$\begin{array}{lcccccc} & \text { Coeff } & \mathrm{se} & \mathrm{t} & \mathrm{p} & \mathrm{LLCI} & \text { ULCI } \\ \text { constant } & 2.1382 & .2594 & 8.2419 & .0000 & 1.6277 & 2.6488 \\ \text { PU } & .2932 & .0480 & 6.1076 & .0000 & .1987 & .3876 \\ \text { SATISFY } & .1317 & .0519 & 2.5389 & .0116 & .0296 & .2338\end{array}$

Source: Primary data

The results in table 4.14 reveal that customer satisfaction is a significant predictor for adoption as a result of perceived use. $(R=0.367, p<0.001)$ with $\mathrm{R}^{2}=13.4 \%$ change in online banking adoption levels. The $\beta=0.132$ for satisfaction. The effect of satisfaction on adoption is further defined by the indirect effect of 0.009 which leads to a total effect of 0.302 when added to a direct effect of 0.293 . (Process procedure matrix in appendix). The finding indicates that there is a partial mediation of customer satisfaction between perceived usefulness and level of adoption.

Satisfaction mediating PEOU and online banking adoption

Table 4.15: Satisfaction mediating PEOU

$\underset{\text { viuuer summily }}{\mathrm{Y}=\mathrm{ADOPTION}} \mathrm{X}=\mathrm{PEOU}, \mathrm{M}=\mathrm{SATISFY}$ Niouer summiny

$\begin{array}{lllllll}\mathrm{R} & \mathrm{R}-\mathrm{sq} & \mathrm{MSE} & \mathrm{F} & \mathrm{df1} & \mathrm{df2} & \mathrm{p} \\ .1891 & .0357 & .3857 & 5.5044 & 2.0000 & 297.0000 & .0045\end{array}$

Model

\begin{tabular}{lcccccc} 
& Coeff. & $\mathrm{se}$ & $\mathrm{t}$ & $\mathrm{p}$ & LLCI & \multicolumn{1}{c}{ ULCI } \\
Constant & 2.9423 & .2724 & 10.7994 & .0000 & 2.4061 & 3.4785 \\
PEOU & .0923 & .0537 & 1.7180 & .0868 & -.0134 & .1980 \\
SATISFY & .1512 & .0547 & 2.7655 & .0060 & .0436 & .2587
\end{tabular}

Source: Primary data

Results in table 4.15 reveal that customer satisfaction partially mediates perceived ease of use and adoption of mobile money. The results revealed that customer satisfaction is a significant predictor for adoption as a result of perceived ease of use $(R=0.189, p=0.0045)$ with $R^{2}=3.57 \%$ change in adoption levels. The $\beta=0.1512$ for satisfaction. The effect of satisfaction on adoption is further defined by the indirect effect of 0.0061 which leads to a total effect of 0.098 when added to a direct effect of 0.092 (Process procedure matrix in appendix). The finding indicates that there is a partial mediation of customer satisfaction between perceived usefulness and level of adoption.

Satisfaction mediating PR and adoption of online banking

Table 4.16: Satisfaction mediating PR

$\mathrm{Y}=\mathrm{ADOPTION}, \mathrm{X}=\mathrm{PR}, \mathrm{M}=\mathrm{SATISFY}$

Model Summary

$\begin{array}{ccccccc}\mathrm{R} & \mathrm{R}-\mathrm{sq} & \mathrm{MSE} & \mathrm{F} & \mathrm{df1} & \mathrm{df2} & \mathrm{p} \\ .3094 & .0957 & .3617 & 15.7201 & 2.0000 & 297.0000 & .0000\end{array}$

Model

$\begin{array}{lcccccc} & \text { coeff } & \text { se } & \mathrm{t} & \mathrm{p} & \text { LLCI } & \text { ULCI } \\ \text { Constant } & 2.2277 & .2867 & 7.7703 & .0000 & 1.6635 & 2.7920 \\ \text { PR } & .3476 & .0727 & 4.7800 & .0000 & .2045 & .4907 \\ \text { SATISFY } & .1284 & .0532 & 2.4137 & .0164 & .0237 & .2330\end{array}$

Source: Primary data

Test results elaborate that customer satisfaction plays a controlling role on perceived risks and adoption of internet banking $(R=0.309, p=0.001)$ with $R^{2}=9.57 \%$ change in adoption levels. The $\beta=0.1284$ for satisfaction. The total effect of change is 0.366 , the direct effect 0.347 , hence indirect effect of 0.018 . Therefore, customer 
satisfaction mediates the effects of PR on adoption of internet banking.

\subsection{Discussions, conclusions and recommendations}

According to the mean statements, the findings report that most of the respondents agreed with the statements about perceived risks. In this context, perceived risks negatively affect adoption as they believe details to their bank accounts are sensitive to different pieces of information online and deem the platform very risky. Regarding perceived usefulness, most respondents agreed that online banking is overall advantageous as it makes it easier to accomplish tasks and generally improves the personal outlook of users. Most respondents also agreed that little mental effort is required to operate internet banking.

Perceived risks (PR) encompasses security and privacy which consumers hold take very seriously. In this study, the overall mean for PR was 2.658 indicating that most of the respondents found e-banking to be very risky. The standard deviation of 1.067 showed that these responses were varied. The correlation coefficient between PR and adoption levels was $\mathrm{r}=0.295$ meaning an increase in PR may not necessarily lead to a decline in adoption levels for this sample population. The $p$-value returned 0.001 therefore statistically very significant. The perception of risk is flamed by the increased degree in inconsistencies between customer judgement and anticipated outcome vis-a-vis the actual behaviour and actual outcome delivered by the technology. This coupled with losses incurred as a consequence of error, fraud or failed systems negatively affects the level at which an individual will adopt internet or online banking. The study surveyed whether an e-banking platform is secure for sending sensitive information, whether it's convenient and saves time or it's expensive and may lead to loss of money in case of errors. It also asked whether users are comfortable and agree with the verification process on the online account. The empirical evidence suggests that e-banking users are not confident in the service and are not willing to take any risks. The online banking environment inherently carries several risks such as lack of compensation or holding contracts in case of errors (Teka, 2020).

For perceived ease of use, the average mean was 3.77 and the standard deviation 1.048. The correlation coefficient was $r=0.104$. These results show that the majority of respondents agreed that online banking is easy to use. The correlation coefficient however reveals a statistically non-significant relationship between the two variables stating that the perceived ease of use may not affect the level of adoption of e-banking. This is in premise with previous studies such as Lema (2017), Al-Jabari (2015), and Bidarra (2013). It is however in contrast with several other researchers that found ease of use to be directly and significantly influential in determining adoption of online banking such as Anouze \& Alamro (2019), Achieng \& Ingari (2015), and Alkhowaiter (2020). The ICT companies in recent years have striven to create cheaper, easy to use and more user-friendly software such as artificial intelligence, machine learning, and robotics. These have greatly affected consumers' attitudes towards adopting online activities. TAM states that perceived ease of use directly and positively affects attitudes towards the acceptance of technology and in the same way predicts perceived usefulness of the stated technology hence increasing adoption yet contradictory to the study results.

The correlation coefficient registered $r=0.341$ and the $p$-values 0.001 purporting a positive and significant relationship respectively for perceived usefulness. This was strengthened by the regression results. Customers' attitudes towards e-banking services are directly influenced by their perception of the usefulness of the technology. When customers discern technology to be time-saving, convenient and offer more advantages compared to traditional banking systems, their attitude towards its adoption will be positive. These results are in line with Davis' (1989) TAM that state that perceived usefulness (PU) positively affects attitudes towards acceptance of a given technology. In this study, the PU was conceived to be more important than PEOU in influencing behavioural intention towards online banking adoption. This is in line with previous studies (see, Teka, 2020; Al-Smadi, 2012; Anyona, 2018). Considering the average mean of 4.15 it can be extrapolated that majority of respondents find ebanking overall to be advantageous and therefore useful in the adoption of online banking by customers.

Results reported that satisfaction has a positive and significant impact on level of adoption of online banking $(R=0.367, p=0.000$ and $\beta=0.131)$ for $\mathrm{PU},(R=0.189, p=0.0045, \beta=0.1512)$, and $(R=0.309, p=0.0000$ and $\beta=0.1284)$. Therefore, the increase in satisfaction level tends to increase adoption of online services for banking. Wandi et al., (2020) in their study on the impact of product and service quality on awareness and customer satisfaction in Islamic banks report a positive and significant effect on quality that results into customer satisfaction. Relatedly, a meta-analysis of 46 studies by Alkhowaiter (2020) observe that behavioural intentions affect customer satisfaction. Also studies like that of Anouze \& Alamro (2019) and Al- Khalaf \& Choe (2020) provide consistent results that support the premise that customer satisfaction is strongly linked to adoption of online banking.

The study analysed factors that affect online banking among customers of commercial banks in Kampala, Uganda. The study adopted a Technology adoption model (TAM) to produce results and concludes as follow:

Customers are willing to adopt online banking if they perceive it to be easy to use. For instance, if it can easily be assessed on several or multiple internet supporting devices, if it does not require a lot of mental effort to operate, and if it is easy to learn and flexible to use. Customers are also willing to adopt and continue usage if they perceive online banking to be useful in their life. Such as if it makes it easier or faster for them to accomplish tasks, provides 
a wider range of information than they would get from a desk at the banking hall, and/or offers them increased prestige, self-image or ranks them as trendy and savvy among their colleagues and peers. However, bank customers might become sceptical and abandon internet banking if the perceived risks increase or surpass any advantages. Such as where it is costly to access online banking, when sharing sensitive information is involved, when the risk of losing money to errors, frauds, and cons are increased. Users also decline online banking with the perception that their age or educational background may hinder their efforts. Most especially because the internet is perceived as a generation $\mathrm{Y}$ and Generation $\mathrm{Z}$ platform. Generation $\mathrm{X}$ and above would rather go to the traditional bank than 'take a risk' on online banks. Customer satisfaction is also very key in mediating the relationships between perceived usefulness, perceived ease of use and perceived risks and online banking adoption.

Therefore, this study recommends that bank customers in Kampala, Uganda adopt online banking solely for reasons associated with its ease of use and usefulness to those who adopt. Online banking requires a good fit between the technology application and users to encourage adoption. This study, therefore, recommends that financial institutions design applications that are simple, precise, and concise to enable understanding and reduce the amount of mental effort required to interact with them. Financial systems and services should be flexible, easily accessible, and easy to learn to encourage adoption. The study also suggests that an online system offers a wider range of information in few clicks and improves customers' prestige and self-image and yet advocates for all regardless of the level of education or age. Financial institutions should therefore invest resources on propositions that will increase online banking that supports the above recommendations. Banks should likewise invest and focus more on ways to profitably reduce perceived risks that customers inhibit. They should introduce more stringent security features such as one-time passwords (OTP), biometrics, two-step verification, and the like to boost customer confidence in the verification and security aspect of online banking. The communities should also be sensitised and addressed through campaigns, promotions, and luring advertisements about security systems put in place and the endless advantages of internet banking to increase usage.

This study however was limited to perceived risks, perceived ease of use, and perceived usefulness and how these can be mediated in their relationship with adoption of online banking with only customers of three banks; Stanbic Bank, Standard Chartered Bank and Centenary Bank within Kampala. A study of all financial institutions in the country might give a different picture on the online banking model. However, several other variables were left out and considered out of scope for this particular study. The study also analysed general online especially ebanking channels. A more specific study on each element of internet banking may have introduced a different series of challenges or explanations for instance why a user may acknowledge EFTs to be riskier than SWIFT. Further research could also be carried out to study more factors affecting adoption such as attitude, customer behaviour, and effort of expectancy to explore more online banking adoption models.

\section{References}

Achieng, B. M., \& Ingari B. K. (2015). Factors influencing the adoption of mobile banking in Kenya's Commercial Banks: A case of Kenya Commercial Bank (KCB) Kilindini Branch. International Journal of Scientific and Research Publications, 5(10), 2250-3153.

Akinyemi, I. O., Asani, E. O., \& Adigun, A, A. (2013). An Investigation of users' acceptance and satisfaction of e-banking system as a panacea towards a cashless economy in Nigeria. Journal of emerging Trends in Computing and Information Sciences, 4(12), 954-963.

Al-Smadi, M. O. (2012). Factors affecting adoption of electronic banking: An analysis of the perspectives of banks' customers. International Journal of Business and social Science, 3(17), 294-309.

Alkhowaiter, W. A. (2020). Digital payment and banking adoption research in Gulf countries: A systematic literature review. International Journal of Information Management, 53, 1-17. https://doi.org/10.1016/j.ijinfomgt.2020.102102

Alliance for Financial Inclusion www.afi-global.org

Al-Khalaf, E. \& Choe, P. (2020). Increasing customer trust towards mobile commerce in a multicultural society: A case of Qatar. Journal of Internet Commerce, 19(1) 32-61.

Anouze, A. L. M. \& Alamro, A. S. (2019). Factors affecting intention to use e-banking in Jordan. International Journal of Bank Marketing, 38, 86-112.

Anyona, G. A. (2018). Factors that influence the adoption of mobile banking financial services in Nairobi county, Kenya (Thesis Strathmore University). Retrieved from: https://suplus.strathmore.edu/handle/11071/6057

Asiyanbi, H. \& Ishola, A. (2018). E-banking services impact and customer satisfaction in selected bank branches in Ibadan metropolis, Oyo state, Nigeria. Accounting, 4(4), 153-160.

Bauer, R. A, (1960), Consumer behaviour as risk taking. In D. Cox (ed.), risk taking information handling in consumer behaviour, Harvard University press, pp. 23-34.

Cai, Y., Yang, Y., \& Cude, B. (2008). Inconsistencies in US consumers' attitude toward and use of electronic banking. Journal of Financial Services Marketing, 13(2), 150-163.

Capgemini, (2020), World Payments Report. 2020: Will COVID-19 spark the end of cash payments 
https://www.capgemini.com/news/capgeminis-world-payments-report-2020/

Davis, F. D., Bagozzi, R. P., \& Warshaw, P. R. (1989). User acceptance of computer technology: A comparison of two theoretical models. Management Science, 35(8), 982-1003.

Davis, F. D. (1989). Perceived usefulness, perceived ease of use, and user acceptance of information technology. MIS Quarterly, 13(3), 319-340.

Floh, A. \& Treiblmaier, H. (2006). What keeps the e-banking customer loyal? A multi-group analysis of the moderating role of consumer characteristics one-loyalty in the financial service industry. Journal of Electronic Commerce Research, 7(2) 97-109.

Fornelle, C. (1992). A national customer satisfaction barometer: The Swedish experience. Journal of Marketing, 56(1), 6-21.

Global Payments, (2020), Transformation and convergence p13 Retrieved from:https:/www.bnymellon.com/content/dam/bnymellon/documents/pdf/articles/global-payments-2020transformation-and-convergence.pdf

https://www.dignited.com/36423/these-banks-provide-online-banking-in-uganda/

https:/www.monitor.co.ug/uganda/news/national/from-bicupuli-cheques-to-atms-the-fast-changing-faces-offinancial-fraud-1869048

Kabir, R. M. (2013). Factors influencing the usage of mobile banking: incident from a developing country. World Review of Business Research, 3(3), 96-114.

Kalakota, R., \& Whinston, A. 1997. E-commerce: A manager's guide, Addison Wesley, Reading, MA.

Karma N. G., Ibrahim S. B., \& Ali A.H., (2014). Key factors affecting mobile banking adoption among banks' customers in Sudan. International Journal of Liberal Arts and Social Science, 2(6), 112-122. www.ijlass.org

Khatoon, S., Zhengliang, X., \& Hussain, H. (2020). The mediating effect of customer satisfaction on the relationship between electronic banking service quality and customer purchase intention: Evidence from the Qatar banking sector. SAGE Open, 10(2). https://doi.org/10.1177/2158244020935887

Kiura, G. S. (2018). Factors influencing the growth of mobile banking services in Kenya. Masters Dissertation, KCA University.

Lee M.C. (2009). Factors influencing the adoption of internet banking: An integration of TAM and TPB with perceived risk and perceived benefit. Electronic Commerce and Applications, 8, 130-141.

Lin W.R., Wang Y.H., \& Hung Y.M. (2020). Analyzing the factors influencing adoption intention of internet banking: Applying DEMATEL-ANP-SEM approach. PLOS ONE, 15(2), 1-25. https://doi.org/10.1371/journal.pone.0227852

Makanyeza, C., (2017). Determinants of consumers' intention to adopt mobile banking services in Zimbabwe. International Journal of Bank Marketing, 35(6) 997-1017. https;//doi.org/10.1108.IJBM-07-2016-0099.

Manju, S. (2020). Customers' perception towards retail banking services of the commercial banks in Mandya town. Studies in Indian Place Names, 40(12), 1163-1174.

Nancy G.K., Siddig, B.L., \& Abdel, H.A. (2014). Key factors affecting mobile banking adoption among banks' customers in Sudan. International Journal of Liberal Arts and Social Science, 2, 112-122.

Ogare, H. O. (2013). The effect of electronic banking on the financial performance of commercial banks in Kenya. $\mathrm{PhD}$ Thesis, University of Nairobi.

Pooya, A., Khorasani, M.A., \& Ghouzdhi, S. G. (2020). Investigating the effect of perceived quality of self service banking on customer satisfaction. International Journal of Islamic and Middle Eastern Finance Management, 13(2), 263-280. https://doi.org/10.1108/IMEFM-12-2018-0440

Roy, P. R. \& Roy, S. S. (2017 Roy, P. R. \& Roy, S. S. (2017), Financial contagion and volatility spillover: An exploration into Indian commodity derivative market. Economic Modelling, 67, 368-380. https://doi.org/10.1016/j.econmod.2017.02.019

Swaid, S., \& Wigand, R. T. (2007). Key dimensions of e-commerce service quality and its relationships to satisfaction and loyalty. eMergence: Merging and Emerging Technologies, Process and Institutions. Bled, Slovenia: 20th Bled e-conference.

Sardana, V. \& Singhania, S. (2018). Digital technology in the realm of banking: A review of literature. International Journal of Research in Finance and Management, 1, 28-32.

Tan, M. \& Teo, T. S. H. (2000). Factors influencing the adoption of internet banking. Journal of the Association for Information System, 1(1), 1-42. DOI: 10.17705/1jais.00005

Teka, B. M. (2020). Factors affecting bank customers' usage of electronic banking in Ethiopia: Application of structural equation modeling (SEM). Cogent Economics and Finance, 8(1). https://doi.org/10.1080/23322039.2020.1762285

Tsanga, R. C.N.N. (2018). What about acceptability of mobile money in Sub-Saharan Africa? The case of Cameroon. Journal of Business and Management Sciences, 6(1), 6-11. https://doi.org/10.12691/jbms-6-1-2

Tseng, C. H. \& Wei, L. F. (2020). The efficiency of mobile media richness across different stages of online consumer behavior. International Journal of Information Management, 50 353-364. 
Venkatesh, V., Morris, M. G., Davis, GB., \& Davis F.D. (2003). User acceptance of information technology: Toward a unified view. MIS Quarterly, 27(3), 425-478. https://doi.org/10.2307/30036540

Wandi, Y., Zainal, V. R., Arafah, W., Subagja, I., Saad, R.A.J. (2020). The effect of service and product quality on customer satisfaction through customer awareness of Islamic banking in West Sumatera, Indonesia. Humanities \& Social Sciences Review. https://doi.org/10.18510/hssr.2020.8182

Yitbarek, T., \& Zeleke, S. (2013). Analysis of factors influencing customers' intention to the adoption of e-banking service channels in Bahir Dar city, Ethiopia: An integration of TAM, TPB and PR. European Scientific Journal, 9(13), 402-417.

Zhang, X., \& Yu, X. (2020). The impact of perceived risk on consumers' cross-platform buying behavior. Frontiers in Psychology, 11(October), 1-13. https://doi.org/10.3389/fpsyg.2020.592246

Zhang, T., Lu, C., \& Kizildag, M., (2018). Banking "on the go". Examining consumers' adoption of mobile banking services". International Journal of Quality and service Sciences, 10(3) 279-295. https://doi.org/10.1108/IJQSS-07-2017-0067

\section{Appendix \\ Appendix 1: Effects of PU on adoption}

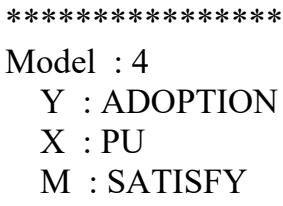

Sample

Size: 300

************** TOTAL, DIRECT, AND INDIRECT EFFECTS OF X ON Y $* * * * * * * * * * * * * *$

Total effect of $\mathrm{X}$ on $\mathrm{Y}$

$\begin{array}{cccccccc}\text { Effect } & \mathrm{se} & \mathrm{t} & \mathrm{p} & \text { LLCI } & \text { ULCI } & \mathrm{c} \text { _ps } & \text { c_cs } \\ .3021 & .0483 & 6.2547 & .0000 & .2071 & .3972 & .4793 & .3407\end{array}$

Direct effect of $\mathrm{X}$ on $\mathrm{Y}$

$\begin{array}{ccccccccc}\text { Effect } & \mathrm{se} & \mathrm{t} & \mathrm{p} & \text { LLCI } & \text { ULCI } & \mathrm{c}^{\prime} \_\mathrm{ps} & \mathrm{c}^{\prime} \_\mathrm{cs} & \\ .2932 & .0480 & 6.1076 & .0000 & .1987 & .3876 & .4651 & .3305\end{array}$

Indirect effect(s) of $\mathrm{X}$ on $\mathrm{Y}$ :

Effect BootSE BootLLCI BootULCI

$\begin{array}{lllll}\text { SATISFY } & .0090 & .0085 & -.0054 & .0301\end{array}$

Partially standardized indirect effect(s) of X on Y:

Effect BootSE BootLLCI BootULCI

$\begin{array}{lllll}\text { SATISFY } & .0142 & .0132 & -.0088 & .0464\end{array}$

Completely standardized indirect effect(s) of X on Y:

Effect BootSE BootLLCI BootULCI

$\begin{array}{lllll}\text { SATISFY } & .0101 & .0094 & -.0060 & .0333\end{array}$

\section{Appendix 2: Effects of PEOU on adoption}

$* * * * * * * * * * * * * *$ TOTAL, DIRECT, AND INDIRECT EFFECTS OF X ON Y

Total effect of $\mathrm{X}$ on $\mathrm{Y}$

\begin{tabular}{ccccccccc} 
Effect & $\mathrm{se}$ & $\mathrm{t}$ & $\mathrm{p}$ & LLCI & ULCI & $\mathrm{c}$ _ps & \multicolumn{2}{c}{ c_cs } \\
.0984 & .0543 & 1.8131 & .0708 & -.0084 & .2052 & .1561 & .1045
\end{tabular}

Direct effect of $\mathrm{X}$ on $\mathrm{Y}$

$\begin{array}{ccccccccc}\text { Effect } & \mathrm{se} & \mathrm{t} & \mathrm{p} & \mathrm{LLCI} & \mathrm{ULCI} & \mathrm{c}^{\prime} \_\mathrm{ps} & \mathrm{c}^{\prime} \_\mathrm{cs} & \\ .0923 & .0537 & 1.7180 & .0868 & -.0134 & .1980 & .1464 & .0980\end{array}$


Indirect effect(s) of $\mathrm{X}$ on $\mathrm{Y}$ :

Effect BootSE BootLLCI BootULCI

$\begin{array}{lllll}\text { SATISFY } & .0061 & .0101 & -.0087 & .0317\end{array}$

Partially standardized indirect effect(s) of X on Y:

Effect BootSE BootLLCI BootULCI

$\begin{array}{lllll}\text { SATISFY } & .0097 & .0157 & -.0142 & .0494\end{array}$

Completely standardized indirect effect(s) of X on Y:

$\begin{array}{lcccc} & \text { Effect } & \text { BootSE } & \text { BootLLCI } & \text { Boot } \\ \text { SATISFY } & .0065 & .0106 & -.0092 & .0332\end{array}$

\section{Appendix 3: Effects of PR on adoption}

$* * * * * * * * * * * * * *$ TOTAL, DIRECT, AND INDIRECT EFFECTS OF X ON Y

Total effect of $\mathrm{X}$ on $\mathrm{Y}$

$\begin{array}{cccccccc}\text { Effect } & \mathrm{se} & \mathrm{t} & \mathrm{p} & \text { LLCI } & \text { ULCI } & \mathrm{c} \_\mathrm{ps} & \mathrm{c} \text { c_cs } \\ .3660 & .0729 & 5.0206 & .0000 & .2225 & .5094 & .5806 & .2793\end{array}$

Direct effect of X on $\mathrm{Y}$

$\begin{array}{ccccccccc}\text { Effect } & \mathrm{se} & \mathrm{t} & \mathrm{p} & \mathrm{LLCI} & \mathrm{ULCI} & \mathrm{c}^{\prime} \_\mathrm{ps} & \mathrm{c}^{\prime} \mathrm{cs} & \\ .3476 & .0727 & 4.7800 & .0000 & .2045 & .4907 & .5514 & .2652\end{array}$

Indirect effect(s) of $\mathrm{X}$ on $\mathrm{Y}$ :

Effect BootSE BootLLCI BootULCI

$\begin{array}{lllll}\text { SATISFY } & .0184 & .0168 & .0006 & .0644\end{array}$

Partially standardized indirect effect(s) of X on Y:

Effect BootSE BootLLCI BootULCI

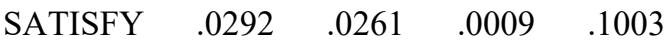

Completely standardized indirect effect(s) of X on Y: Effect BootSE BootLLCI BootULCI

$\begin{array}{lllll}\text { SATISFY } & .0140 & .0126 & .0004 & .0482\end{array}$ 